\title{
KETERAMPILAN MENULIS TEKS NARASI EKSPOSITORIS PESERTA DIDIK KELAS VII-F SMP NEGERI 31 BANJARMASIN
}

\author{
SKILLS WRITING EXPOSITORIZED NARRATIVE TEXT \\ PARTICIPANTS IN CLASS VII-F SMP NEGERI 31 BANJARMASIN
}

\author{
Syirmadinah; Rusma Noortyani; Lita Luthfiyanti \\ Program Studi Pendidikan Bahasa dan Sastra Indonesia \\ FKIP Universitas Lambung Mangkurat \\ syirmadinah1998@gmail.com
}

\begin{abstract}
Abstrak
Penelitian ini bertujuan mendeskripsikan keterampilan menulis teks narasi ekspositoris peserta didik kelas VII-F SMP Negeri 31 Banjarmasin. Penelitian ini dilakukan dengan metode kualitatif. Hasil tes menulis yang telah didapatkan yaitu peserta didik kelas VII-F SMP Negeri 31 Banjarmasin tidak memuat 17 kriteria yang telah ditentukan. Kriteria yang banyak dimuat peserta didik, seperti alur, tokoh, latar tempat, sudut pandang, orientasi, kata ganti orang, dan kata latar tempat. Kriteria yang tidak banyak dimuat peserta didik, seperti watak, latar waktu, latar suasana, komplikasi, resolusi, kata latar suasana, kata latar waktu, kata sambung urutan waktu, ungkapan terkejut, dan penggunaan dialog. Peserta didik kelas VII-F SMP Negeri 31 Banjarmasin dominan mendapatkan nilai 75 atau kategori baik.
\end{abstract}

Kata kunci: keterampilan menulis, teks narasi ekspositoris

\begin{abstract}
This study aims to describe the expository narrative text writing skill of VII-F grade students of SMP Negeri 31 Banjarmasin. This research was conducted using qualitative methdos. Writing test results that have been obtained are students of class VII-F SMP Negeri 31 Banjarmasin does not contain 17 predetermined criteria. Criteria that are mostly loaded by students, such as plot, charachter, setting, perspective, orientation, personal, pronouns, and place background words. Criteria that are not widely loaded by student, such as character, setting of time, setting, complicatoins, resolution, setting of atmosphere, setting of time, conjunction of time, expression of surprise, and use of dialogue. Students in class VII-F of 31 State Junior High School Banjarmasin predominantly scored 75 or both categories.
\end{abstract}

Keywords: writing skills and expository narrative text

\section{Pendahuluan}

Pelajaran bahasa Indonesia selalu ada dalam pembelajaran di sekolah. Pelajaran bahasa bertujuan agar peserta didik mampu berkomunikasi menggunakan bahasa Indonesia yang baik dan benar. Terampil berbahasa dalam pembelajaran bahasa Indonesia ada empat aspek keterampilan berbahasa, yaitu keterampilan menyimak, keterampilan berbicara, keterampilan membaca, dan keterampilan menulis. Keterampilan berbahasa harus terus menerus dilakukan karena dari seringnya berlatih dapat memberi ilmu pengetahuan kepada peserta 
didik dan masyarakat terutama keterampilan menulis atau berbahasa.

Keraf dalam Zulela Ms, dkk. (2017:113) mengungkapkan bahwa narasi adalah sebuah percakapan yang akan digambarkan dengan jelas tentang kejadian/peristiwa yang pernah terjadi dalam kesatuan waktu. Jadi, narasi adalah kegiatan tulis-menulis siswa dalam menuangkan ide pikiran yang berasal dari pengalaman yang pernah terjadi dari penulisnya lalu dituangkan ke dalam tulisan sesuai alur atau kejadian cerita atau narasi.

Pengalaman pribadi atau ekspositoris akan membiasakan peserta didik untuk berpikir nyata karena sesuai kejadian yang pernah terjadi. Dengan demikian, apa yang ditulis peserta didik merupakan hasil yang diperoleh dari kejadian yang pernah di alami oleh peserta didik. Pengalaman pribadi membuat peserta didik percaya diri dalam menulis karena tulisan akan dibaca oleh orang lain. Selain itu, peserta didik dapat berbagi pengalaman bukan hanya kepada teman sekelas tetapi juga pada keluarga. Pengalaman pribadi termasuk cerita atau teks narasi.

Memilih keterampilan menulis karena menulis termasuk ranah keterampilan yang ada dalam kurikulum 2013. Kurikulum 2013 lebih mengembangkan kognitif peserta didik terkait dengan daya kreasi, penyelidikan, dan daya imajinasi, hal tersebut berkaitan dengan visi pemerintah. Visi pendidikan tahun 2025 menyatakan akan menciptakan rakyat Indonesia yang cerdas dan berdaya saing. Cerdas tersebut bukan hanya cerdas pikiran tetapi juga, seperti kemampuan dan keterampilan, yaitu cerdas intelektual dalam ranah pengetahuan dan cerdas dalam ranah keterampilan. Jadi, bukan hanya materi saja yang diungkapkan dalam kurikulum 2013 tetapi juga memuat keterampilan.

Rumusan masalah dalam penelitian ini, yaitu bagaimanakah keterampilan menulis teks narasi ekspositoris siswa kelas VII-F SMP Negeri 31 Banjarmasin dan tujuan dalam penelitian ini yaitu mendeskripsikan keterampilan menulis teks narasi ekspositoris siswa kelas VII-F SMP Negeri 31 Banjarmasin.

\section{Metode Penelitian}

\section{Jenis Penelitian}

Jenis penelitian adalah deskriptif kualitatif. Deskriptif kualitaif analisis datanya berupa kata-kata tertulis atau mendeskripsikan hal yang akan dibahas. Penelitian kualitatif lebih menonjolkan perspektif subjek. Penelitian kualitatif mengguakan landasan teori agar penelitian fokus pada pembahasan. Landasan teori juga bermanfaat untuk memberikan gambaran bahan pembahasan hasil penelitian. 


\section{Waktu dan Tempat Penelitian}

Waktu penelitian dilaksanakan pada tanggal 2 September 2019. Penelitian ini dilakukan di kelas VII-F SMP Negeri 31 Banjarmasin yang berlokasi di Jalan Antasan Kecil Timur RT.18 Kecamatan Banjarmasin Utara, Kota Banjarmasin, Kalimantan Selatan. Kelas VII-F dipilih karena kelas tersebut telah memasuki materi bab 2 atau narasi. SMP Negeri 31 Banjarmasin dipilih karena Akreditas sekolah tersebut A serta menggunakan kurikulum 2013.

\section{Target atau Subjek Penelitian}

Subjek penelitian adalah peserta didik kelas VII-F SMP Negeri 31 Banjarmasin yang berjumlah 29 orang. Namun, dalam pengambilan data hanya 28 orang yang hadir, 1 orang tidak hadir karena sakit. Objek penelitian adalah hasil keterampilan menulis teks narasi ekspositoris siswa kelas VII-F SMP Negeri 31 Banjarmasin.

\section{Prosedur}

Peneliti melakukan observasi dan wawancara tidak terstruktur dengan guru Bahasa Indonesia di SMP Negeri 31 Banjarmasin. Setelah itu, peneliti melakukan pengumpulan data berupa teks narasi ekspositoris yang ditulis oleh peserta didik.

\section{Data, Instrumen, dan Teknik \\ Pengumpulan Data}

Data yang akan diteliti berupa kata, kalimat, paragraf dalam tulisan teks narasi ekspositoris. Tes yang digunakan berupa tes tertulis. Instrumen yang digunakan adalah tes.

\begin{tabular}{|c|c|c|c|}
\hline No & Aspek yang dinilai & Kriteria & Skor \\
\hline \multirow[t]{7}{*}{1} & \multirow{7}{*}{$\begin{array}{l}\text { Kelengkapan unsur } \\
\text {-unsur narasi }\end{array}$} & Alur & 5 \\
\hline & & Tokoh & 5 \\
\hline & & Watak & 5 \\
\hline & & Latar tempat & 5 \\
\hline & & Latar waktu & 5 \\
\hline & & Latar suasana & 5 \\
\hline & & Sudut pandang & 5 \\
\hline \multirow[t]{3}{*}{2} & \multirow{3}{*}{$\begin{array}{l}\text { Kelengkapan } \\
\text { struktur narasi }\end{array}$} & Orientasi & 5 \\
\hline & & Komplikasi & 10 \\
\hline & & Resolusi & 5 \\
\hline \multirow[t]{7}{*}{3} & \multirow{7}{*}{$\begin{array}{l}\text { Kelengkapan ciri } \\
\text { kebahasaan }\end{array}$} & Penggunaan kata ganti orang & 5 \\
\hline & & Kata latar tempat & 5 \\
\hline & & Kata latar suasana & 10 \\
\hline & & Kata latar waktu & 5 \\
\hline & & Kata sambung urutan waktu & 10 \\
\hline & & Kata ungkapan terkejut & 5 \\
\hline & & Penggunaan dialog & 5 \\
\hline \multicolumn{3}{|r|}{ TOTAL } & 100 \\
\hline
\end{tabular}

Gambar 1. Kriteria Penilaian keterampilan Menulis Teks Narasi Ekspositoris

Tes tersebut berupa menulis teks narasi ekspositois peserta didik. Peserta didik diberi waktu selama 1 jam pelajaran untuk menulis pengalaman. Teknik pengumpulan data yang digunakan dalam penelitian yaitu, 1. Teknik observasi, kegiatan observasi dalam penelitian ini dilakukan dua tahap yaitu sebelum penelitian dan sesudah penelitian. 
Observasi pada penelitian ini adalah melakukan kegiatan pengamatan dan mencatat hal yang berkaitan dengan tujuan penelitian, 2. Wawancara, wawancara yang dilakukan yaitu wawancara tidak terstruktur atau tidak direncanakan terlebih dahulu. Wawancara berkaitan dengan kelas VII. Kelas VII yang mempunyai minat menulis kelas VII-F dan kelas VII yang lain mempunyai minat menggambar. Kelas VII-F sudah memasuki mata pelajaran narasi atau pada bab II, 3. Teknik pengukuran, tes yang digunakan dalam penelitian ini adalah tes tertulis. Peneliti memberikan tugas berupa tes menulis narasi ekspositoris memuat 17 kriteria.

Setiap kriteria mempunyai skor, skor tersebut berasal dari pembagian setiap skor untuk mendapatkan nilai keseluruhan yaitu 100. Jadi, setiap skor kriteria dijumlahkan dan akan mendapat nilai sesuai kategori, 4. Dokumen, Sugiyono (2014:240) menyatakan bahwa dokumen adalah catatan peristiwa yang berbentuk tulisan, gambar atau karya dari seseorang. Dokumen pada penelitian ini berupa hasil keterampilan menulis teks narasi ekspositoris. Hasil menulis tersebut digunakan sebagai bukti bahwa tulisan diperoleh dari peserta didik.

\section{Teknik Analisis Data}

1. Mereduksi data

Catatan pada penelitian ini direduksi dan menghasilkan gambaran yang jelas tentang hasil pengamatan sebelum dan sesudah dilakukannya penelitian.

2. Menampilkan data

Penelitian ini membuat grafik sesuai nilai yang didapat dari penjumlahan setiap skor kriteria agar nilai kategori yang didapatkan oleh peserta didik dapat dilihat jelas.

3. Mengambil kesimpulan

Kesimpulan berupa makna dari data yang telah dikumpulkan. Kesimpulan pada penelitian ini didapatkan dari nilai yang ada pada grafik.

\section{Hasil Penelitian dan Pembahasan \\ Hasil Keterampilan Menulis Teks Narasi Ekspositoris}

Hasil penelitian ini diperoleh dari hasil keterampilan peserta didik dalam menulis teks narasi ekspositoris yang telah dilakukan. Hasil atau data tes menulis yang telah didapatkan yaitu peserta didik kelas VII-F SMP Negeri 31 Banjarmasin tidak memuat semua kriteria yang telah ditentukan.

Kriteria yang banyak dimuat oleh peserta didik dalam tulisan karena mudah dipahami, kriteria tersebut berupa alur, tokoh, latar tempat, sudut pandang, 
orientasi, kata ganti orang, dan kata latar tempat. Kriteria yang tidak banyak dimuat peserta didik dalam tulisan karena kurang memahami dan bingung, kriteria tersebut seperti watak, latar waktu, latar suasana, komplikasi, resolusi, kata latar suasana, kata latar waktu, kata sambung urutan waktu, ungkapan terkejut, dan penggunaan dialog.

\section{Pembahasan Keterampilan Menulis Teks Narasi Ekspositoris}

\begin{tabular}{|c|c|c|c|}
\hline No & Kode & Skor & Jumlah \\
\hline 1 & A1 & $5,5,5,5,5,5,5,5,5,5,10$ & 60 \\
\hline 2 & A2 & $5,5,5,5,5,5,5,5,5,5,10,5,10$ & 75 \\
\hline 3 & A3 & $5,5,5,5,5,5,5,5,5,5,5,10$ & 65 \\
\hline 4 & A4 & $5,5,5,5,5,5,5,5,5,5,10$ & 60 \\
\hline 5 & A5 & $5,5,5,5,5,5,5,5,10,5,5,5,10,5,5$ & 85 \\
\hline 6 & A6 & $5,5,5,5,5,5,5,5,5,10,5,10$ & 70 \\
\hline 7 & A7 & $5,5,5,5,5,5,5,5,5,10$ & 55 \\
\hline 8 & A8 & $5,5,5,5,5,5,5,5,5,5,10,5,10$ & 75 \\
\hline 9 & A9 & $5,5,5,5,5,5,5,5,5,5,10$ & 60 \\
\hline 10 & A10 & $5,5,5,5,5,5,5,5,10,5,5,5,10,5,5$ & 80 \\
\hline 11 & A11 & $5,5,5,5,5,5,5,10,5,5,5,5,10,5$ & 80 \\
\hline 12 & A12 & $5,5,5,5,5,5,5,5,5,10$ & 55 \\
\hline 13 & A13 & $5,5,5,5,5,10,5,5,5,10$ & 60 \\
\hline 14 & A14 & $5,5,5,5,5,5,5,10,5,5,5,10,5,10$ & 85 \\
\hline 15 & A15 & $5,5,5,5,5,10,5,5,5,10$ & 60 \\
\hline 16 & A16 & $5,5,5,5,5,5,10,5,5,10,5,5$ & 70 \\
\hline 17 & A17 & $5,5,5,5,5,5,5,10,5,5,10,5,10$ & 80 \\
\hline 18 & A18 & $5,5,5,5,5,5,5,10,5,5,5,5,10$ & 75 \\
\hline 19 & A19 & $5,5,5,5,5,5,5,5,5,10,5,10,5$ & 75 \\
\hline 20 & A20 & $5,5,5,5,5,5,5,10,5,5,10,5,10,5$ & 85 \\
\hline 21 & A21 & $5,5,5,5,5,5,5,5,5,5,10,5,10$ & 75 \\
\hline 22 & A22 & $5,5,5,5,5,5,5,5,5,10,5,10$ & 70 \\
\hline 23 & A23 & $5,5,5,5,5,5,5,10,5,5,10,5,5,5$ & 80 \\
\hline 24 & A24 & $5,5,5,5,5,5,5,5,5,5,5$ & 55 \\
\hline 25 & A25 & $5,5,5,5,5,5,5,5,5,5,10,5,10$ & 75 \\
\hline 26 & A26 & $5,5,5,5,5,5,5,5,10$ & 50 \\
\hline 27 & A27 & $5,5,5,5,5,5,10,5,5,5,5,10$ & 70 \\
\hline 28 & A28 & $5,5,5,5,5,5,5,5,10,5,5,5,10,5,5$ & 85 \\
\hline & & & \\
\hline
\end{tabular}

Gambar 2. Jumlah Pemerolehan Skor

\section{Alur}

Alur terbagi menjadi dua, yaitu alur maju dan alur mundur. Peserta didik kelas VII-F SMP Negeri 31 Banjarmasin menggunakan alur maju dan alur mundur dengan cerita yang sederhana. Peserta didik menggunakan alur maju karena di awali dengan pengenalan tokoh, latar tempat, dan waktu.

\section{Tokoh}

Peserta didik kelas VII-F SMP Negeri 31 Banjarmasin menggunakan tokoh diawali pengenalan keluarga, ayah, ibu, kakak, adik, paman, kakek, nenek.

Tokoh yang dipilih peserta didik kelas VII-F SMP Negeri 31 Banjarmasin menggunakan "aku" dan "saya". Tokoh "aku" dan "saya" banyak digunakan peserta didik karena sesuai dengan judul skripsi yaitu ekspositoris atau pengalaman pribadi. Tokoh tambahan juga ada dalam tulisan seperti keluarga yaitu teman dan sahabat. Keluarga dan teman dipilih peserta didik karena tokoh tersebut ada dalam keseharian peserta didik seperti di rumah dan di sekolah.

\section{Watak}

Watak terbagi menjadi dua, yaitu watak secara langsung dan secara tidak langsung. Watak secara tidak langsung dapat diamati melalui, a) perilaku tokoh ke lawan bicara dan b) sesuai ucapan tokoh dalam cerita. Peserta didik memuat watak seperti baik, pemarah, penakut dan usil.

\section{Latar Tempat}

Latar tempat yang digunakan dalam cerita peserta didik kelas VII-F SMP Negeri 31 Banjarmasin yaitu disekitar rumah, sekolah, bandara, dan 
tempat wisata. Latar rumah yang digunakan umum seperti, kamar, ruang tamu, dan teras. Latar sekolah digunakan karena keseharian seorang peserta didik yaitu berada di sekolah.

Latar tempat saat berada di bandara digunakan karena tujuan wisata ke luar kota seperti ingin pulang ke kampung halaman atau ingin jalan-jalan. Latar tempat yaitu tempat wisata yang dikunjungi peserta didik sangat umum atau sudah diketahui semua orang seperti waterboom, pantai, gunung, mandi angin, mall, pantai Bali, dan objek wisata Jawa.

\section{Latar Waktu}

Latar waktu yaitu, pagi hari, siang hari, sore hari dan malam hari. Latar waktu pagi hari digunakan saat aktivitas peserta didik di sekolah, mempersiapkan barang untuk berwisata, mandi, shalat dan keberangkatan ketujuan wisata. Latar waktu siang hari digunakan saat peserta didik berada di perjalanan, pulang sekolah, makan siang, shalat, pergi eskul ke sekolah, tertidur dalam mobil dan berada di tempat wisata.

Latar waktu sore hari digunakan saat bersantai di tempat wisata, berfoto, bermain, melihat matahari terbenam dan perjalanan pulang setelah berwisata. Latar waktu malam hari juga digunakan saat perjalanan pulang setelah berwisata, dan tidur setelah kelelahan beraktivitas.

\section{Latar Suasana}

Latar suasana menyenangkan banyak digunakan peserta didik seperti saat berwisata ke pantai, mendapatkan kejutan, dan pulang kampung. Latar suasana menyedihkan juga dipilih oleh peserta didik saat menceritakan perpisahan dengan teman dan sahabat. Latar suasana kecewa juga digunakan oleh peserta didik saat terpisah dengan teman dan dimarahi oleh orang tua. Latar suasana takut saat belajar naik sepeda motor, belajar berenang, dan masuk rumah sakit. Latar suasana kaget dalam cerita yang ditulis oleh peserta didik seperti terpeleset, terjepit di exapator mall, dijepit kepiting dan tertumpah minyak di kaki.

\section{Sudut Pandang}

Sudut pandang orang pertama lebih banyak digunakan karena peserta didik merasa bahwa cerita tersebut merupakan pengalaman yang pernah terjadi. Sudut pandang aku atau saya digunakan peserta didik saat melakukan kegiatan atau aktivitas sendiri.

Sudut pandang ia, dia, nya, mereka digunakan peserta didik saat penulis tidak ada dalam cerita tetapi sebagai pengamat seperti menceritakan tindakan yang dilakukan seseorang. Sudut pandang kami atau kita digunakan peserta didik saat penulis ada dalam cerita dan melakukan kegiatan atau aktivitas bersama-sama 
seperti berenang di pantai, jalan-jalan ke mall.

\section{Orientasi}

Peserta didik dikatakan memuat orientasi dapat dilihat pada awal cerita yaitu pengenalan tokoh, latar tempat, dan waktu terjadi. Pengenalan tokoh yang didapat dalam tulisan peserta didik seperti ayah, ibu, kakak, adik, kakek, nenek, teman dan sahabat. Pengenalan latar tempat, peserta didik menunjukkan latar tempat dalam cerita sesuai aktivitas atau tempat yang ingin dikunjungi, seperti ingin pergi ke pantai, waterboom, mall. Pengenalan waktu selalu digunakan dalam cerita. Peserta didik menunjukkan waktu seperti jam, hari, tanggal dan bulan.

\section{Komplikasi}

Komplikasi atau permasalahan sebatas masalah kecil yang terjadi antara teman atau antara keluarga. Masalah yang terjadi antara teman seperti permasalahan saat bermain dan saat di sekolah. Masalah yang terjadi antara keluarga seperti permasalahan saat diminta orang tua untuk melakukan sesuatu.

\section{Resolusi}

Resolusi atau menutup cerita dengan keadaan yang dialami setelah beraktivitas seperti gembira, kelelahan, dan perjalanan pulang hingga tiba di rumah. Keadaan gembira diungkapkan peserta didik saat sudah sampai di rumah. Keadaaan kelelahan yang banyak digunakan oleh peserta didik seperti saat sudah ngantuk diperjalanan sampai menceritakan bahwa peserta didik tersebut langsung tertidur di kamar.

\section{Kata Ganti Orang}

Kata ganti digunakan peserta didik, seperti "Ipul adalah temanku". "Dia temanku dari kecil sampai sekarang". Kata dia digunakan untuk mengganti kata Ipul. "Kakakku itu orangnya agak nakal, saat aku belajar berenang sama dia. Peserta didik dapat menggunakan kata dia untuk mengubah kata kakak.

\section{Kata Latar Tempat}

Kata latar tempat tersebut seperti "pada hari senin saya dan teman-teman saya SD saya piknikan ke Pantai Tangkisung". Kata pantai tangkisung adalah latar tempat yang akan dikunjungi. Pemikiran peserta didik SMP menyukai hal yang diungkapkan secara langsung dan tidak menyukai basa-basi.

\section{Kata Latar Suasana}

Kata latar suasana terbagi menjadi dua yaitu secara langsung dan tidak langsung. Ungkapan secara langsung adalah penyebutan suasana secara spontan. Ungkapan secara tidak langsung adalah penyebutan suasana secara tidak spontan 
atau ada basa-basi saat menyatakan suasana.

Ungkapan suasana secara langsung yaitu peserta didik langsung mengungkapkan bagaimana suasana yang terjadi saat itu seperti "aku sangat senang bisa jalan-jalan bersama keluarga." Ungkapan secara tidak langsung yaitu peserta didik mengungkapkan dengan tindakan seperti "aku berenang di pantai seperti lumba-lumba dan menikmati pemandangan yang sangat indah”.

\section{Kata Latar Waktu}

Latar waktu dimuat oleh peserta didik dalam tulisan. Peserta didik mengungkapkan waktu seperti "matahari mulai tenggelam kami memutuskan untuk pulang" dan "pagi hari yang cerah kami berangkat ke bandara".

\section{Kata Sambung Urutan}

Kata sambung yang banyak ditemuakan dalam tulisan, seperti setelah itu dan lepas itu. Kalimat "lepas itu kami naik bus" termasuk kata sambung paling banyak digunakan peserta didik. Peserta didik kelas VII-F sudah dapat menggunakan kata lepas itu dalam menyambung urutan waktu karena tidak semua orang menggunakan kata lepas itu dalam cerita.

\section{Ungkapan Terkejut}

Ungkapan terkejut yang digunakan, seperti ternyata, terkejut, tiba-tiba dan kaget. Contoh dari salah satu tulisan peserta didik, seperti "ternyata ada orang tabrakan. Contoh tersebut jika dibaca secara sekilas, dapat dipahami bahwa ada hal yang membuat terkejut. Hal tersebut yaitu tabrakan sehingga mengakibatkan kemacetan.

\section{Penggunaan Dialog}

Penggunaan dialog dalam cerita sangat sederhana, seperti berbicara saat marah, menolak sesuatu, membangunkan teman, dan memberi amanat. Isi dialog berupa hal yang sehari-hari dilakukan dan menjadi permasalahan. Dialog yang digunakan tidak terlalu panjang.

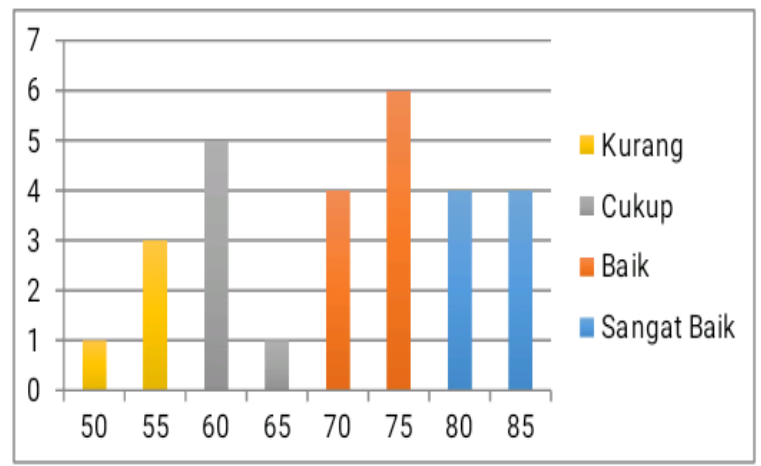

Gambar 3. Jumlah skor peserta didik 


\section{Simpulan dan Saran}

\section{Simpulan}

Peserta didik kelas VII-F SMP Negeri 31 Banjarmasin lebih dominan menggunakan Alur maju. Tokoh dominan menggunakan tokoh utama dan tambahan. Watak dominan menggunakan tidak langsung. Latar tempat dominan menggunakan latar pantai. Latar waktu dominan menggunakan waktu pagi hari. Latar suasana dominan menggunakan suasana senang. Sudut pandang dominan menggunakan orang pertama tunggal (aku atau saya).

Orientasi digunakan semua peserta didik. Komplikasi digunakan 13 orang peserta didik. Resolusi dominan menutup cerita menggunakan suasana gembira. Kata ganti orang menggunakan aku atau saya. Kata latar tempat digunakan semua peserta didik. Kata latar suasana digunakan 14 orang peserta didik. Kata latar waktu digunakan 23 orang peserta didik. Kata sambung urutan waktu dominan menggunakan setelah itu. Ungkapan terkejut dominan menggunakan ternyata. Penggunaan dialog digunakan 7 orang peserta didik

\section{Saran}

Setelah dilakukannya penelitian, peneliti memberikan saran, sebagai berikut. 1. Guru disarankan memiliki keterampilan menulis yang lebih baik, agar peserta didik dapat mencontoh keterampilan menulis yang baik, 2. Peserta didik disarankan untuk lebih aktif dan lebih giat dalam berlatih menulis karangan narasi. Bukan hanya teks narasi saja tetapi juga harus berlatih menulis teks lainnya, 3. Peneliti yang sedang melakukan penelitian mengenai keterampilan menulis teks narasi sugesti atau khayalan dan teks lainnya, hendaknya termotivasi dengan penelitian ini dan penelitian ini semoga bisa memberikan hal yang baik untuk peneliti lain.

\section{Daftar Pustaka}

Ahsin, M. N. (2016). Peningkatan Keterampilan Menulis Karangan Narasi Dengan Menggunakan Media Audiovisual Dengan Metode Quantum Learning. Jurnal Refleksi Edukatika Vol 6 No2 , 158-171.

Ardianto, E. (2016). Metodologi Penelitian Untuk Public Relation Kuantitatif dan Kualitatif. Bandung: Simbiosa Rekatama Media .

Astuti, Y. W., \& Mustadi, A. (2014). Pengaruh Penggunaan Media Film Animasi Terhadap Keterampilan Menulis Karangan Narasi Siswa Kelas V SD. Jurnal Prima Edukasi , 23.

Dalman. (2016). Keterampilan Menulis. Jakarta: PT RajaGrafindo Persada.

Depdiknas. (2003). Kurikulum 2004; Standar Kompetensi Kelas V Sekolah Dasar Madrasah Ibtidaiyah. Jakarta: Puskur Dit PTK-SD. 
Fadillah, M. (2014). Implementasi Kurikulum $2013 \quad$ Dalam Pembelajaran SD/MI SMP/MTs SMA/MA. Yogyakarta: Ar-ruzz Media.

Harsiati, T., Trianto, A., \& Kosasih, E. (2017). Bahasa Indonesia / Kementrian Pendidikan dan Kebudayaan. Jakarta: Kementerian Pendidikan dan Kebudayaan.

Ishak, S. (2014). Cara Menulis Mudah. Jakarta: PT Elex Media Komputindo.

Kemendikbud. (2013). Buku Siswa Bahasa Indonesia Ekspresi Diri dan Akademik. Jakarta: Kementerian Pendidikan dan Kebudayaan.

Keraf, G. (2003). Argumentasi dan Narasi. Jakarta: PT. Gramedia Pustaka Utama.

Kundoro Saddhono, S. (2014). Pembelajaran Keterampilan Berbahasa Indoesia. Yogyakarta: Graha Ilmu.

Lasol, A. I. (2017). Peningkatan Kemampuan Menulis Kata Dalam Teks Narasi Ekspositoris Melalui Model Pembelajaran Bersiklus (Cycle Learning) Pada Siswa Kelas VIII C SMP NEgeri 3 Manokwari. Jurnal Triton Pendidikan Vol 2 No 1, 69-80.

Lestari, R. S. (2014). Peningkatan Keterampilan Menulis Karangan Narasi Melalui Pendekatan Kontekstual dengan Media Gambar Seri pada Siswa Kelas IVB SDN Wonosari Pasuruan. Jurnal Pedagogy vol 1 (2) , 88120.

Malang, U. N. (2017). Pedoman Penulisan Karya Ilmiah. Malang: UM PRESS.

Margono, S. (2003). Metodologi Penelitian Pendidikan . Jakarta: PT Rineka Cipta .

Much, H. T. (2017). Pendekatan Kontekstual Dengan Inspirator Lingkungan Sekolah Siswa Kelas
VII SMP Negeri 1 Sano Nggoang, Manggarai Barat Tahun Pelajaran 2016/2017. Jurnal Ilmiah Mandala Education Vol 3 No 1 , 301-313.

Muchlishoh. (1992). Materi Pokok Bahasa Indonesia. Jakarta: Departemen Pendidikan dan Kebudayaan.

Mulyati, E. (2018). Meningkatan Kemampuan Menulis Karangan Narasi Melalui Pendekatan Kontekstual Dengan Insprator Lingkungan Sekolah Kelas VII SMP Negeri 1 Wera Tahun Pelajaran 2016/2017. Jurnal Ilmu Sosial dan Pendidikan Vol 2 No 1 , 284-303.

Ningsi, N. P. (n.d.). Kemampuan Menulis Karangan Narasi Melalui Media Animasi Siswa Kelas VIII SMP Negeri 07 Palopo. Jurnal Onoma Vol 3 No 1, 44-56.

Nurgiyantoro, B. (2018). Penilaian Otentik Dalam Pembelajaran Bahasa. Yogyakarta: Gadjah Mada University Press.

Prisna Destia, P. U., \& Arifin, M. (2017).

Kemampuan Menulis Teks Karangan Narasi Siswa Kelas X SMK Negeri 03 Model Invest Kota Bengkulu. Jurnal Korpus Vol 1 No 2 , 166-172.

Pujiono, S. (2013). Terampil Menulis Cara Mudah dan Praktis dalam Menulis. Yogyakarta: Graha Ilmu.

Rahardi, K. (2009). Penyuntingan Bahasa Indonesia. jakarta: Erlangga.

Rohmat, P. S. (2019). Penelitian Kualitatif. Jurnal Equilibrum , 20-23.

Sabarti Akhadiah, S. R. (1986). Menulis I. Jakarta: Universitas Terbuka.

Suci Rahmadani, S., \& Arifin, M. (2017). Kemampuan Menulis Teks Narasi Tentang Pengalaman Libur Sekolah Siswa Kelas VII SMP Negeri 1 Beriman Ilir Kabupaten Kapahiang. Jurnal Ilmiah Korpus Vol 1 No 1 , 218-223. 
Supriyadi. (2013). Evalausi Pembelajaran

Bahasa Indonesia. Gorontalo:

UNG Press Gorontalo.

Yusuf, A. (2013). Peningkatan

Kemampuan Menulis Karangan

Narasi Berdasarkan Pengalaman

Pribadi dengan Strategi Genius

Learning pada Siswa MI Darut

Taqwa Pasuruan. Jurnal

Pendidikan Humaniora Vol 1 No $1,1-8$.

Zulela Ms, dkk. (2017). Keterampilan Menulis Narasi Melalui

Pendekatan Kontrutivisme di

Sekolah Dasar. Jurnal Pendidkan

Dasar Vol 8 No 2 , 112-123. 